\begin{tabular}{|c|c|c|}
\hline 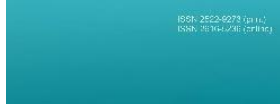 & & $\begin{array}{l}\text { ISSN 2522-9273 (print) } \\
\text { ISSN 2616-5236 (online) }\end{array}$ \\
\hline & & $\begin{array}{l}\text { Economies' Horizons, No. } \\
\text { 2(9), pp. 112-117. }\end{array}$ \\
\hline 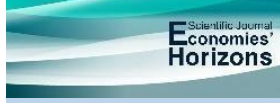 & Homepage: http://eh.udpu.edu.ua & DOI: $\frac{\text { https://doi.org/10.31499/2616- }}{5236.2(9) \cdot 2019.230431}$ \\
\hline
\end{tabular}

UDC 65.012 .123

JEL Classification: C15 E27 F47

\title{
The current state of marketing activities of agricultural enterprises in Ukraine
}

\author{
Olha H. Chyrva ${ }^{1}$, Doct. Ec. Sc., Professor \\ Maksym.V. Boyko ${ }^{2}$, graduate student
}

\begin{abstract}
The aim of the study. The purpose of the article is to analyze the current state and trends in the marketing activities of enterprises of the agro-industrial complex of Ukraine. Methodology. In the study of the state and trends of marketing activities of agricultural enterprises of Ukraine used a graphical method and systematic analysis; in the study of the impact of threats on the state of marketing activities of agricultural enterprises in Ukraine - the causal method and the method of scientific generalization in forming the conclusions of the study. Results. The results of the study were summarized with the help of SWOT-analysis, which allowed to systematize the tools for marketing activities of agricultural enterprises. Thus, the results of the evaluation of the effectiveness of marketing policy of agricultural enterprises, according to the respondents, confirmed the importance of marketing policy to ensure their economic security. According to the results of the study, the development trends of agricultural enterprises are analyzed, the effectiveness of the marketing policy of agricultural enterprises is diagnosed, the main factors influencing the state of economic security of agricultural enterprises are assessed. The practical significance of the study is that the main conclusions and suggestions can be used by domestic enterprises to form an effective management system for marketing activities of agricultural enterprises. Prospects for further research. It is determined that in the long run for agricultural enterprises in developing marketing policy as a tool for economic security and for making sound management decisions and in the interests of consumers of agricultural products in the region it is necessary to form strategic and tactical goals based on the proposed tools.
\end{abstract}

Keywords: marketing, marketing activities, agro-industrial complex, agricultural enterprises, marketing tools.

\footnotetext{
${ }^{1}$ Pavlo Tychyna Uman State Pedagogical University; Director of the Educational and Scientific Institute of Economics and Business Education; Professor at the Department of Marketing, Management and Business Management; ORCID: https://orcid.org/0000-0003-0601-0624; e-mail: chyrva81@ukr.net

${ }^{2}$ Uman State Pedagogical University named after Pavel Tychyna; postgraduate; ORCID: https://orcid.org/0000-00026649-5021; e-mail: max@ukr.net
} 
Number of references: 9; number of tables: 1;number of figures:1; number of formulas: 0.

\section{Сучасний стан маркетингової діяльності підприсмств АПК в Україні}

\section{О.Г. Чирва ${ }^{1}$, д.е.н., професор}

\section{М. В. Бойко ${ }^{2}$, аспірант}

Анотація. Мета дослідження. Мета статті полягає в аналізі сучасного стану та тенденцій розвитку маркетингової діяльності підприємств агропромислового комплексу України.

Методологія. При дослідженні стану й тенденцій маркетингової діяльності підприємств АПК України використано графічний метод та системний аналіз; при дослідженні впливу загроз на стан маркетингової діяльності підприємств АПК в Україні - причинно-наслідковий метод та метод наукового узагальнення - при формуванні висновків дослідження.

Результати. Результати проведеного дослідження були узагальнені за допомогою SWOT-аналізу, що дозволило систематизувати інструменти забезпечення маркетингової діяльності сільськогосподарських підприємств. Таким чином, результати оцінки ефективності маркетингової політики сільськогосподарських підприємств, на думку опитаних респондентів, підтвердили важливість маркетингової політики для забезпечення їх економічної безпеки. За результатами дослідження, проаналізовано тенденції розвитку сільськогосподарських підприємств, здійснено діагностику ефективності маркетингової політики сільськогосподарських підприємств, оцінено основні чинники впливу на стан економічної безпеки сільськогосподарських підприємств.

Практичне значення дослідження полягає в тому, що основні висновки та пропозиції можуть бути використані вітчизняними підприємствами для формування ефективної системи управління маркетинговою діяльністю сільськогосподарських підприємств.

Перспективи подальших досліджень. Визначено, що на перспективу для сільськогосподарських підприємств при розробці маркетингової політики як інструменту забезпечення економічної безпеки та для прийняття обгрунтованих управлінських рішень та в інтересах споживачів сільськогосподарської продукції регіону необхідним $є$ формування стратегічних і тактичних цілі діяльності на основі запропонованого інструментарію.

Ключові слова: маркетинг, маркетингової діяльності, агропромисловий комплекс, сільськогосподарські підприємства, маркетингові інструменти.

Кількість джерел: 9; кількість таблиць:1; кількість рисунків: 1; кількість формул: 0.

\footnotetext{
${ }^{1}$ Уманський державний педагогічний університет імені Павла Тичини; директора Навчально-наукового інституту економіки та бізнес-освіти; професор кафедри маркетингу, менеджменту та управління бізнесом; ORCID: https://orcid.org/0000-0003-0601-0624; e-mail: chyrva81@ukr.net.

${ }^{2}$ Уманський державний педагогічний університет імені Павла Тичини; асnірант; ORCID: https://orcid.org/00000002-6649-5021; e-mail:max@ukr.net
} 
1. Introduction. Market transformation requires the readiness of all businesses to work in conditions of risk and uncertainty, in which all business processes are affected by the external and internal environment, the relevance of which necessitates management decisions.

The success of agricultural enterprises, under such conditions, is determined not only by the establishment of domestic economic activity, but also their ability to adapt to a rapidly changing environment, which, given the economic and natural features of Ukraine, is extremely unstable. The economic growth of agricultural enterprises is determined by the formation and implementation of effective marketing policies, which, in turn, is an important tool for ensuring their economic interest, forecasting the level of strategic development and the formation of competitive advantages.

Problem statement. However, there are a number of problems that need further development, in particular, modern approaches to determining the state of marketing activities of agricultural enterprises in Ukraine.

2. Literature review. The basics of the formation of marketing policy of agricultural enterprises is the field of research of many domestic scientists, including: A. Bancheva (2006), T. Zhdanova (2019), M. Kasatkina (2011), N. Kotenko, S. Serdyuk, G. Saltikova (2015), V. Lazurenko, O. Posylkina, T. Maksimova (2010), V.Musatkina (2014), O.Rubtsova (2018), I. Smirnov, O. Lyubitseva (2020), та інші.

3. Methodology. The article uses a graphical method and systematic analysis in the study of the state and trends of marketing activities of agricultural enterprises of Ukraine; in the study of the impact of threats on the state of marketing activities of agricultural enterprises in Ukraine - the causal method and the method of scientific generalization - in forming the conclusions of the study.

4. Research objectives. The purpose of the article is to analyze the current state and trends in the marketing activities of enterprises of the agro-industrial complex of Ukraine.

\section{Results and discussions.} Agricultural enterprises react quickly to changes in the market, can quickly change their production programs depending on the influence of environmental factors, so they require a special marketing approach. The effectiveness of management decisions in the marketing activities of agricultural enterprises depends entirely on the degree of development of marketing and the development of its organizational and economic principles. Therefore, the issue of effective marketing policy of agricultural enterprises is relevant, based on special techniques and the use of specific tools, rational methods of marketing management, taking into account the size, type and specifics of enterprises.

The effectiveness of the marketing policy of agricultural enterprises is one of the key indicators in the activities of any enterprise, which shows the degree of achievement of the goals set by the marketing department.The use of marketing in domestic enterprises has become widespread and is an integral part of most businesses, but unfortunately we see a fragmentary use of only some marketing functions, which reduces the overall effectiveness of marketing activities. The formation of the marketing complex of the enterprise is the main task for marketing services, but the 
management of the marketing complex is not the only task that arises in the management of marketing activities.

The main features of the marketing policy of agricultural enterprises are highlighted, on the basis of which the author's concept of "agricultural policy of marketing" is proposed.

Marketing policy is a component of the overall domestic economic policy, the formation of which is the most important task of the enterprise in the future.

During September 2018 - September 2019, a survey was conducted among the owners and management of agricultural enterprises, the results of which identified the main factors influencing the implementation of their marketing policy. Representatives of 51 agricultural enterprises took part in the survey, including: from Cherkasy region. (27\%), Zhytomyr region. (23\%), Kyiv region. (19\%), Poltava region. (18\%), Vinnytsia region. (13\%) and other areas. The main elements of marketing policy that allow to gain competitive advantage, respondents named: the uniqueness of agricultural products of the enterprise (78\%); quality of agricultural products of the enterprise (65\%); modern production technologies (59\%); focusing on specific consumers (53\%). Among the main threats to the economic security of agricultural enterprises, respondents named: a narrow range of products $(84 \%)$; fixed market prices $(76 \%)$; limited involvement of financial resources for business expansion (72\%); and low efficiency of marketing policy (69\%).According to respondents, the main tools by which agricultural enterprises can ensure their economic security are to increase financial resources for development (36\%), domestic production capacity $(31 \%)$, as well as the development and implementation of effective marketing policy (28\%) .

To conduct a SWOT analysis in order to develop a marketing policy, the agricultural enterprise must pay attention to the following factors:

- market capacity of the agricultural enterprise;

- attractiveness of the market for agricultural products;

- marketing policy of competitors of the agricultural enterprise;

- competitive advantages of the agricultural enterprise;

- potential of agricultural enterprise;

- specifics of agricultural products;

- costs of production and marketing of agricultural enterprises;

- interests of management and employees;

- quality composition and qualification of the personnel of the agricultural enterprise; - the degree of dependence on the external environment;

- financial resources of the enterprise; - level of risk.

The results of the study were summarized with the help of SWOTanalysis, which allowed to systematize the tools for economic security of agricultural enterprises, and to identify among them the tools of marketing policy. The results of the study showed that if the management of the agricultural enterprise does not know the strengths and weaknesses, does not imagine external opportunities and does not suspect threats, can not identify paired combinations between these elements, it will not be able to develop effective marketing policies enterprises.

The most complete assessment of the effectiveness of marketing policy can be done by identifying and analyzing specific indicators of the effectiveness of management measures, including, for example, the effectiveness of current costs of marketing, efficiency of marketing 
processes, efficiency of management resources.

Given the above, for an effective marketing policy use indicators that focus on qualitative analysis of marketing activities of enterprises:

- the degree of adaptation of the strategy in a certain period of time to a specific scenario of the external environment;

- the ratio of the share of profit or income received from marketing activities and related costs;

- the ratio of the economic effect obtained from the implementation of the logistics concept to the amount of capital invested in logistics;

- ranking the importance of messages, which allows you to consider the most important of them first.

The modern system of effective marketing policy of agricultural enterprises must also take into account the possibility of disseminating information via the Internet, which is an indispensable tool for obtaining fresh marketing information.

We believe that the choice of the form of effective marketing policy depends on the peculiarities of the functioning of agricultural enterprises such as: the size of the enterprise, development period, life cycle and so on.Thus, in order to achieve the goals and objectives set by the agricultural enterprise, all internal processes and conditions must meet and promote the implementation of strategic objectives, and the mechanism of marketing policy of agricultural enterprises must be customer-oriented and have a certain level of competence. Businesses that optimize their internal processes make a profit.

A consumer-oriented agricultural enterprise that is able to anticipate and meet its needs will get the expected result in the long run. An important place of activity of an agricultural enterprise should be given to the choice and justification of such a marketing policy, which will allow it to occupy a profitable niche in the market of agricultural products and promote further development. The choice and justification of strategic management of the enterprise should be based on integrated marketing.

Based on the data obtained from the SWOT analysis, the development of marketing policy of the agricultural enterprise also involves the choice of tools for marketing policy in general and in each area in particular.

Consider the most effective tools for implementing the marketing policy of an agricultural enterprise in more detail:

1) advertising is a proven method of promoting and promoting a product / brand. Despite the constant adjustments in the methods of its conduct (primarily the transition to digital promotion), advertising remains the most effective marketing tool to this day.2) In recent years, personalized marketing has become a personification of digital promotion, which involves the collection of analytical data on the target audience and the use of this data in order to more accurately and effectively promote the product / service / brand.

3) Among the most effective methods of personalization - linking with social networks, working with subscribers, questionnaires, targeting in Google Analytics.

4) The use of software tools can be very helpful in organizing a digital marketing campaign for agricultural enterprises. Various ready-made templates and graphic editors allow you to create your own corporate identity in the web environment, while saving time and money.

The use of ready-made marketing solutions allows agricultural enterprises to 
individualize the account, make it authentic, recognizable and attractive to the target audience.

Thus, the results of the evaluation of the effectiveness of marketing policy of agricultural enterprises, according to the respondents, confirmed the importance of marketing policy to ensure their economic security.

\section{Conclusions.}

Thus, according to the results of the study of the current state of marketing activities in agricultural enterprises, it is established that the main factors influencing the implementation of their marketing policy are: the uniqueness of agricultural products of the enterprise; the quality of agricultural products of the enterprise; modern production technologies; focusing on specific consumers. Among the main threats to the economic security of agricultural enterprises, respondents named: a narrow range of products; fixed market prices; limited financial resources for expansion; and low efficiency of marketing policy.

The results of the study were summarized with the help of SWOTanalysis, which allowed to systematize the tools for economic security of agricultural enterprises, and to identify among them the tools of marketing policy. Thus, the results of the evaluation of the effectiveness of marketing policy of agricultural enterprises, according to the respondents, confirmed the importance of marketing policy to ensure their economic security.

\section{References}

Bancheva A.A., (2006). Development of the concept of market-oriented management. Marketing. №2. Pp. 3-12.

Zhdanova T.S., (2019). Lazy marketing. Principles of passive sales. URL: https://www.klex.ru/9uy.

Kasatkina M.V., (2011). Assessment of the competitiveness of the chemical industry: methodological aspects. Marketing and innovation management. № 3 (2). Pp. 159165. URL: http://nbuv.gov.ua/UJRN/Mimi_2011_3\%282\%29_24.

Kotenko N.V., Serdyuk S.G., Saltikova G.V., (2015). Marketing tools for managing the financing and promotion of NGO services. Marketing and innovation management. № 4. pp. 20-33.

Lazurenko V., Posylkina O.V. Research of evolution of scientific approaches to definition of essence of partnership relations. URL: https://dspace.nuph.edu.ua/bitstream/123456789/18158/1/226-229.pdf.

Maksimova T.S. (2010). Innovative tools of direct marketing. Marketing and innovation management. № $1 . \quad$ pp. 78-81. URL: Access mode: http://nbuv.gov.ua/UJRN/Mimi_2010_1_11.

Musatkina V.P. (2014). The impact of marketing policy on the productivity of a commercial enterprise. Scientific Bulletin of Mukachevo State University. Economics series. Issue 1 (1). Pp. 101-104.

Rubtsova O.S. (2018), Features of accounting for marketing costs of construction companies. Efficient economy. № $12 . \quad$ URL: http://www.economy.nayka.com.ua/?op=1\&z=6782. DOI: 10.32702 / 2307-21052018.12.105.

Smirnov I.G., Lyubitseva O.O. (2020). Marketing of sustainable tourism: a text. 256 s. 